\title{
TOLERANCE AS AN IMPERATIVE FOR HIGHER EDUCATION AND DEMOCRACY
}

\author{
N. Davids \\ Department of Education Policy Studies \\ Stellenbosch University \\ Stellenbosch, South Africa \\ e-mail: nur@sun.ac.za
}

\section{ABSTRACT}

Beyond the noise and din of the numerous \#FeesMustFall campaigns, there arose deeper concerns of the lack of regard on display not only between protesters and institutional authorities, but between protesting and non-protesting students. Of course, protests by their nature are manifestations of perceivably unheard and unrecognised demands and plights, which make the flaring of tempers inevitable. But, perhaps, what defined the student protests most distinctly were not the impassioned calls for economic accessibility, transformation, and decolonisation, but its volatility, and, at times, sheer contempt. The concern of this article is to offer a conceptual consideration of tolerance as an educational imperative within higher education, and democracy. That is, if higher education is to fulfil its responsibility in relation to the public good, then it has to espouse those virtues that are most likely to contribute to peaceful and harmonious co-existence. Keywords: higher education, violence, hate speech, tolerance, democracy, educational imperative

\section{HIGHER EDUCATION AS SITES OF INTOLERANCE}

The concern and prevalence of intolerance in higher education takes on many different forms, and manifests in varying contexts and cuts across various constructions of racial, religious, ethnic, or economic groups. At institutional level, one finds intolerant repression of liberal and conservative views alike. In 2014, Anita Sarkeesian, a feminist writer, cancelled a speech at Utah State University after the institution received threats that a deadly shooting would take place if she appeared. Sarkeesian responded that she viewed this lack of tolerance, lack of openness to different ideas as a serious failing of higher education (Reisberg 2014). In 2015, Germaine Greer, another feminist and activist defied a fierce campaign to stop her delivering a university lecture at Cardiff University, on the grounds that she had expressed transphobic views. In responding to what she described as a "worrying trend", Nicola Dandridge, chief executive of Universities UK, said that "One of a university's main roles in society is to encourage critical thinking and vigorous debate .... Occasionally this will involve inviting speakers who will express contentious, even inflammatory or offensive views" (The Guardian 
2015). In 2017, left-wing protesters threw smoke bombs and flares at far-right journalist, Milo Yiannopoulos, at the University of California-Berkeley. In response to this "worrying trend", the American-based, Foundation for Individual Rights in Education (FIRE) has coined the term "disinvitation" to refer to speakers, who have been disinvited, after invited to speak at universities (Lukianoff 2017). Between 2000 and 2017, FIRE had discovered 192 incidents in which students or faculty had pushed for speakers to be disinvited. Of these 192, 82 were successful in that the speaker did not speak. And of those 82, 53 occurred via the revocation of the speaker's invitation to campus; 17 were from speakers withdrawing in the face of protest; and 12 were "heckler's vetoes" in which speakers were shouted down, chased off stage, or otherwise prevented from speaking (Lukianoff 2017).

Expressions of intolerance are in no way limited to invited guests. A study by Fosnacht and Broderick (2017) found that approximately one in four students experienced religious intolerance at least once in the past year, with Jewish and Muslim students being particularly vulnerable to religious discrimination (Bauer-Wolf 2017; Dreid 2016). In South Africa, a Report by the Ministerial Committee on Transformation and Social Cohesion and the Elimination of Discrimination in Public Higher Education Institutions revealed that while racism continues to be a problem in higher education, xenophobia, sexual harassment, and gender discrimination are equally pervasive (DoE 2008). At times, as Bothwell (2017) points out, it is not just that intolerance is common among university students, what is more concerning is that they use their university education to justify prejudices against minority groups, such as gays and lesbians, as is the case at institutions in China - where a number of postgraduate students shared the opinion, that to their "medical knowledge", homosexuality is a "type of mental illness" (Bothwell 2017). Intolerance, which often descends into violence, is especially rife during student protests. In 2011, South Korean universities in Seoul and a number of other universities were destabilised by the resurgence of the call from students to reduce tuition fees (Kim 2011). In 2015, student protests on the streets of London against tuition fees quickly spiralled into violence, leading to widespread damage to property, and the subsequent arrest of twelve students (Hughes and Harley 2015). In turn, recent student protests on South African campuses against university fees, have been notably characterised by violence, wanton destruction to property and others. These have included arson, damage to lecture theatres, libraries, vehicles, statues, artworks as well as confrontations with security staff and police, and brutal clashes between student factions (MacGregor 2016; Hall 2016).

There are, of course, a number of complex reasons for the current crises besetting higher education in South Africa. According to Badat $(2010,7)$ on the one hand, there is a strain between a number of values and goals of higher education. On the other hand, the extent to 
which government and universities have sought to pursue social equity and redress and quality in higher education simultaneously, has resulted in difficult political and social dilemmas, which often spill over into conflict and violence. One of the main challenges is inadequate public finances and academic development initiatives to support under-prepared students, who tend to be largely black, or of working class or rural poor social origins. Much of the challenges and protests encountered in university spaces, as Hall (2016), explains stems from decades of colonialism, apartheid, racial discrimination, high levels of unemployment and income inequality. To Hall (2016), therefore, it is necessary and important to make sense of the crises in higher education in relation to the intersections between historical legacies and contemporary inequalities and inequities.

Inasmuch as student protests have resulted in increasing levels of violence, intimidation and assault between students, as well as between students and academics and other university employees, the effects of the violence have been far-reaching.

"The protesting students marched through the rain to residences across the university to gather numbers. Once numbers grew to around 150 students, the group moved across the campuses, disrupting lectures and exams. One of the exams disrupted was the Postgraduate Diploma in Accounting exam, where students stormed into the UCT Sports Centre and let off a fire extinguisher in the venue." (Swingler 2017).

In addition to the above, students have been involved in forcing students out of libraries, lecture theatres, disrupting examinations, and forcing non-protesting students to participate in the protests. While disruptions, such as these, have become synonymous with student protests, particularly in South Africa, what has made the latest spate of protests especially disturbing and distressful is the resort to intolerance, as manifested in hate speech. The University of Witwatersrand (Wits) has had phrases of "Kill a Jew" spray-painted on one of its main buildings. Also at Wits, a voice note on social media claimed that in order to get ViceChancellor Professor Adam Habib's attention, one white student would need to die. At the University of the Western Cape, the message "Kill All Whites" was spray-painted on university property. A student at the University of Cape Town student wore a t-shirt, displaying a similar message. To Suttner (2016), the \#FeesMustFall and \#RhodesMustFall campaigns may raise wider questions that go beyond the educational realm and offer a lens through which we can look at post-1994 South Africa and ask troubling questions about the nature of this society.

These troubling questions, as will be addressed in this article, include the importance of tolerance not only among students, and all individuals, but as an educational imperative, and necessary for human flourishing. 


\title{
HIGHER EDUCATION AND CONTESTATIONS OF BEING AND ACTING
}

Few would disagree with Davies (2015) that higher education institutions should be places of fierce debate, arguments over right and wrong, or with Bothwell (2017), that one of the frequently cited benefits of higher education is its role in producing graduates who embrace tolerance and progressive thinking. In an interview with Dawes (2014), Giroux contends as follows:

\begin{abstract}
"Higher education must be understood as a democratic public sphere - a space in which education enables students to develop a keen sense of prophetic justice, claim their moral and political agency, utilize critical analytical skills, and cultivate an ethical sensibility through which they learn to respect the rights of others. Higher education has a responsibility not only to search for the truth regardless of where it may lead, but also to educate students to make authority and power politically and morally accountable while at the same time sustaining a democratic, formative public culture. Higher education may be one of the few public spheres left where knowledge, values, and learning offer a glimpse of the promise of education for nurturing public values, critical hope, and a substantive democracy."
\end{abstract}

Notably, following on Giroux (in Dawes 2014), is the attention to the responsibility of higher education in instilling notions of "moral and political agency", as well as moral accountability within students. Again, few would argue with this view, because, if nothing else, higher education ought to prepare students how to behave, how to respect, and how to distinguish between good and bad. There is an implicit societal expectation and assumption - which, of course, is contestable - that educated individuals ought to exercise reason, and act responsibly. As Pring $(2013,12)$ contends, the educated person, may not be academically shining, "but would have this sense of direction in life activities, informed by a critical sense of what is worthwhile, of what has wider social usefulness, and through which he or she gains a sense of personal worth". The problem and difficulty, however, with the expectation that higher education can, and will fulfil this mandate in cultivating students, who are morally responsible, is three-fold.

Firstly, state Aronowitz and Giroux (2000, 333), the corporatisation of higher education, has reconceptualised social issues as increasingly individual or economic considerations, thereby erasing democratic impulses by either devaluing them or absorbing such impulses within marketplace demands. In Aronowitz and Giroux's (2000) opinion, the more corporate culture and values shape university life, the more corporate planning replaces social planning. In turn, they continue, management becomes a substitute for leadership, while the private domain of individual achievement replaces the discourse of public politics and social responsibility. Secondly, as Sandalow $(1991,150)$ brings to our attention, although universities are in many respects different, diverse, and complex institutions, the question of their apposite 
role in shaping a social morality is part of a larger problem that our society is yet to address satisfactorily. He explains that the ideas that society has about moral responsibility have been shaped in reference to individuals, which cannot readily be transferred to institutions (Sandalow 1991, 150). And thirdly, according to Davies (2015), higher education institutions are probably the worst educational sites to establish definitive duties.

Unlike schools, universities have a larger body of students, who come from vastly diverse social, economic, racial and cultural identities. For the majority of students in South Africa, universities present the first opportunity through which they encounter students from different racial and cultural demographics. In turn, university life is often the first time that students leave the comfort and familiarity of their homes, and are introduced to the unknown rituals and traditions of university residences. For students, who come from historically disadvantaged backgrounds and schooling, the spaces of historically advantaged institutions, are particularly daunting and alienating. In sum, students often feel displaced from the dominant institutional culture, and struggle to find spaces and emotions of belonging. As a result, students are already in a vulnerable space, which is further complicated by stresses of financial insecurity. They might see protests as a last resort for assistance, and when this is not forthcoming, they might interpret the actions of university authorities as not only unsupportive and unsympathetic, but exclusionary. It is important to consider Davies's (2015) argument that university students are often not really part of their community, but occupy islands of somewhat artificial activity.

Now, if one takes into account the above three complexities, as enunciated by Aronowitz and Giroux (2000), Sandalow (1991), and Davies (2015), and couple these with the particular contexts of higher education in South Africa, then one begins to get some sense of the underlying anger, frustration and hopelessness that, no doubt, clouds the majority of students. On the face of it, the series of protests that have, at times, paralysed higher education institutions, is about free education, and hence, equal opportunity, and the promise of a gateway to economic prosperity. But the desire for free education is neither the source nor the solution to the anger festering in the language and physical displays of intolerance. There are bigger and deeper issues at play here. These are issues fuelled by generational forms of alienation, colonisation, and dehumanisation. What the protests are a reflection of, is anger against an unrealised democracy. Promises of a better life have been made, wrongs were supposed to be corrected, but more than two decades later, very little has changed for most South Africans leading Badat $(2016,19)$ to refer to the protests as "a dramatic reminder of unfinished business in higher education". Indeed, as violence and intimidation became a common occurrence at universities, so, too, the list of demands became longer and longer - from free tuition, and free accommodation, to free meals, after-hours transportation, and condoms. 
Higher education cannot and should by no means be expected to fulfil the myriad social demands invoked by protesting students. Higher education cannot be a surrogate welfare state. Higher education cannot be responsible, or held to ransom for what are clearly political and socio-economic problems, and often beyond the brief and ambit of university authorities. If students are calling for free education, then the state needs to be held to account for, and to that call. Similarly, if students are resorting to wanton acts of violence, which includes the burning of buildings and assault of their peers, then, these, too, are not problems only for higher education. These actions are infringements on societal norms and regulations, and cannot be treated as if they are not criminal acts.

What higher education, however, should be called out on, and held accountable for, is its increasingly volatile and intolerant educational spaces, and its impact and responsibility not only to its on-campus communities, but to the communities in which it finds itself. In other words, universities cannot afford to be dismissive or non-responsive in the face of intolerant hate speech, and intimidation. These forms of violation and humiliation hold deep implications for democracy, in that it inevitably festers into more intolerance, hatred and disregard for the other. The irony is that inasmuch as student protests have spilled over into calls for the decolonisation of education, the epistemic violence inflicted through colonisation, is alive and well in the violence of students. And unless, higher education takes (epistemic) stock of its moral responsibility in nurturing students, who act with humanity, moral responsibility and compassion in relation to themselves and others, the violent legacies of colonisation and apartheid will continue to thrive. As I will argue in the ensuing sections of this article, higher education institutions, therefore, have to become spaces of regard for the other, and this regard has to be imbibed in conceptions of tolerance as an educational imperative.

\section{WHY TOLERANCE?}

Generally, when we think of tolerance, we associate it with patience and open-mindedness. In the Socratic sense, tolerance is synonymous with pursing truth, and being prepared to consider the truths of others. Being prepared to consider that there are other ways of seeing and understanding the world, implies an understanding that the world is necessarily a place of disagreement, and at times, conflict. In other words, disagreement and conflict are not necessarily signs of discontent, disharmony and friction, but rather that competing views are indeed being engaged and debated. To exercise tolerance in relation to differences of opinion, therefore, is, as Murphy $(1997,596)$, describes, to show "the self-restraint of not restricting or reducing the rights or autonomy of others, or other ways of being and acting". In a similar fashion, Fiala $(2002,103)$ defines tolerance as a pragmatic response to the practical need to 
coexist with others who have different conceptions of the good. According to Fiala $(2002,103)$, tolerance "develops out of the recognition that in practice diversity cannot be eradicated by either philosophical argument or political force". Rather, individuals and society have to consciously work at allowing voices of competing views, and to accept that consensus on these views, are not necessarily a goal.

To Gutmann $(1987,304)$, tolerance is an act "agreeing to disagree about beliefs and practices that are a matter of basic liberty". This, states Gutmann (1987) serves as a way to expand and extend participation of people as civic equals in such encounters. She maintains that once an individual has agreed to disagree in educational encounters, the possibility exists to recognise publicly one another's political, cultural and religious differences (Gutmann 1987, 305). In this way, tolerance and recognition of differences are inseparable acts of human behaviour. To Gutmann $(1987,304)$, tolerance prevents the imposition of any single substantive systems of beliefs and practices on all others, because in showing tolerance, an individual recognises that others hold different perspectives on the world and on themselves. The argument being made here, is that exercising tolerance is contingent upon the capacity of humans to agree to disagree about matters that influence them. In other words, the very idea of tolerance infers an understanding that people cannot be expected to be in agreement about everything or everyone, and more importantly, that people have the right to express their disagreement or difference.

Following Gutmann (1987), tolerance can be understood as an imperative for both civic and moral equality. That is, to show regard for divergent views is not limited to practices of civil engagement. Rather, to act with tolerance is to afford and affirm the equal rights of all individuals to lay claim to what they consider as their truths. This does not mean that tolerance should be (mis)interpreted as a licence for people to simply say and do as they please. Students, for example, even in their most frustrated moments, cannot be allowed to vandalise university property, or spew hate speech, and then claim these as legitimate forms of protest. As Gutmann $(1987,308)$ clarifies, tolerating all people is conditional upon a concern that differences should not be of such a nature that it could result in people doing harm to one another. For this reason, Walzer (1997) describes tolerance as the key virtue for peaceful co-existence and a necessary condition for human flourishing, while Fiala $(2002,103)$ defines tolerance as a pragmatic response to the practical need to coexist with others who have different conceptions of the good.

In continuing, tolerance, contends Walzer (1997), does not suggest the agreement with or acceptance of another's perspective or truth. A preparedness or willingness to engage with another perspective, does not mean that one accepts that perspective. In this sense, there might be shared understandings that students should not be prevented from pursuing higher education 
due to financial constraints - that is, that all students should be afforded equal social and economic opportunities. Within this shared agreement, there is acceptance of one another's actions or practices. Notions of tolerance only enter the debate when there is disagreement about how the desire for equal opportunities might be attained - for example, whether preventing students from writing their examinations is an acceptable form of protest. Here, the argument might be that all students ought to make sacrifices so that the greater good (of free higher education) might be reached. In turn, the counter argument might be that inasmuch as students have the right to protest, others have the right not to participate in the protest. In other words, tolerance only comes into play when there are differences of opinion. It is only through disagreement or dissensus that the need for tolerance arises - that is, tolerance emanates from divergence and difference. According to MacIntyre (2006, 289), the urgency of tolerance often manifests in the minor confrontations, contending interests, unremitting suspicions and diversity of standpoints involving human agency.

Following the above explications, tolerance is limited to the recognition of people's competing conceptions of the good life for as long as such conceptions do not result in doing harm to others. To this end, tolerance does not imply an uncritical and disengaged acceptance of whatsoever. One cannot make an argument for tolerating violence and intimidation, when such acts have the potential to bring about harm. As an educational imperative, tolerance has to be enacted as a reflective practice in relation to oneself and others - affording due regard to diverse ways of thinking, being, and acting (Davids and Waghid 2017).

\section{TOLERANCE AS AN EDUCATIONAL IMPERATIVE}

In a Foucauldian sense, higher education, as powerful sites of learning, will never be without resistance. Knowledge, and knowledge production, are always immersed in power. As Giroux (in Giroux and Samalavicius 2016) contends, higher education is not simply about educating young people to be smart, socially responsible and adequately prepared for whatever notions of the future they can imagine, but that higher education is central to democracy itself. In this regard, the real challenge for higher education, argues Giroux (1992, 7), is to extend its definition beyond "the more vital imperatives of educating students to live in a multicultural world, to face the challenge of reconciling difference and community, and to address what it means to have a voice in shaping one's future as part of a broader task of enriching and extending the imperatives of democracy and human rights on both a national and global level". Such an understanding, according to Giroux (1992, 7), makes students attentive to their own roles and responsibilities in relation to human suffering; it makes them more inclined towards compassion and empathy. 
What, therefore, can institutions of higher education do in order to ensure that students are attentive to their own implication in particular forms of human suffering - such as when hate speech is scrawled across campus walls? What types of teaching and learning should take shape so that all students are not only included, but that any form of marginalisation and exclusion, is collectively guarded against by all? How should universities extend the imperatives of a democracy, so that students know how to be, and act in a democracy? In the concluding sections of this article, I explore the importance of tolerance as an educational imperative, and depart from a premise that an educational encounter should necessarily be shaped by practices of deliberation and engagement - that is, where students are invited to critically engage with their own teaching and learning, without coercion, and without fear of reprisal.

Implicit within the conceptions of tolerance, as highlighted in this article, is an assumption that an individual exercises his or her conscience on the basis of his or her own autonomous self. This implies that an individual is free to act in an unhindered way, while also having an awareness that this freedom or autonomy would need to be harnessed or inhibited in relation to others (Davids and Waghid 2017). A teacher, for example, might have particular religious beliefs or affiliations. These beliefs might constrain and prejudice how he or she views individuals from other religious affiliations. In a certain context, when he or she is with those, who share these particular beliefs, it might be in order for him or her to express these views. But, in a different context, such as a classroom, it might be inappropriate or downright offensive for him or her to verbalise these views. In this way, the context of the encounter influences the autonomy of the teacher - that is, whether he or she has the autonomy to express him or herself in an unhindered manner. Similarly, a university teacher might have particular dissident views on LGBTQI students, but would need to constrain these views in the classroom, so as not to cause umbrage to others.

Exercising tolerance of conscience is thus tantamount to an action of will on the grounds that the individual is prepared to constrain his or her speech and feelings in relation to others about a particular matter, say, in an educational encounter (Davids and Waghid 2017). In this regard, Oshana $(1998,81)$ maintains, "autonomy is a condition of persons constituted, in large part, by the external, social relations people find themselves in (or the absence of certain social relations)". The autonomous person, states Oshana $(1998,82)$, formulates certain goals, which are constructed according to particular values, desires and convictions that have developed in an uncoerced and conscious fashion (Oshana, 1998, 82). When individuals attune themselves to particular values, they are, according to Pring (2013), able to recognise others as well as themselves as individuals - capable of understanding, seeking personal fulfilment, and worthy of respect. 
Following the above, students should be made aware that inasmuch as they have the right to embark on protest, as an enactment of their autonomy, they also need to understand that their actions need to be informed by practical reasoning or rationality. In other words, their actions, which constitute their exercise of autonomy, have to be enacted, with due regard for the other. A student, for example, through practical reasoning, would know, that wearing a t-shirt, emblazoned with hate speech, might cause harm to another. By enacting his or her autonomy to wear the t-shirt, he or she might alienate another. Alienation is incommensurate with human flourishing, and contradistinctive to peaceful co-existence, and, therefore, should be guarded against within any setting (Davids and Waghid 2017)

If we agree with Giroux (in Giroux and Samalavicius 2016), that higher education is central to democracy, then the focus has to be on the cultivation of contesting voices and spaces, without the intention of harm and wilful alienation. One way of doing this, is what MacIntyre $(1999,27)$ describes as exercising rational agency to make judgements based on powers of perception, identification and re-identification. The importance of teachers listening to students, and students listening to others, is not so much about the sharing of experiences as it is about the capacity it holds for helping us to understand ourselves in relation to those who shape our relationships (Davids 2016). To MacIntyre (1999, 30), exercising independent rational choices on the grounds of articulating autonomous "speech acts" involves making assertions, and expressing doubts through asking questions. Secondly, for MacIntyre (1999, 14), practical rationality requires of humans to engage with others so that might make sense of their speech, and come to understand the perspectives of others - thereby, embarking on activities "in concert and communication with others" (MacIntyre 1999, 51).

The idea of engaging with others on the basis of practical rationality, argues MacIntyre $(1999,84)$, is linked to an understanding that although humans have the capability to reach their own conclusions, they can also be held accountable for those conclusions. Stated differently, practical rationality can be described as humans simply using their common sense. In this way, an acknowledgement of autonomous human action is inextricably linked to a dependence on others for their intelligible contributions. Thirdly, to MacIntyre $(1999,54)$, exercising practical rationality is an ability to stand back from one's initial opinions and judgements, and to reconsider how things might be otherwise in relation to other and competing judgements. This implies that once one has proffered reasons in defence of a particular argument, one also demonstrates an ability to distance oneself from one's earlier reasons because one is capable to come up with more imaginative reasons for different possible futures (MacIntyre 1999, 74). This ability reveals a capacity not only to shift in one's thinking, but to imagine a different future. It is possible, therefore, for students to make their challenges and concerns known and 
attended to, without a resort to violent protest.

A student, for example, might use violence as a means of protest, but then upon reevaluating the consequences, as in destroyed libraries and lecture theatres, might realise that violence might not be the best path of action. Or, he or she might violate others through offensive slogans, but when confronted with similar vile statements regarding his or her own identity, might begin to know the pain of hate speech. It is therefore critical to higher education that spaces and opportunities are created and cultivated where students are allowed to bring their perceptions, worldviews, and prejudices into the room. When students are prepared to bring their prejudices and conflicts into an educative setting, they should be equally prepared to listen to those, who have divergent views, or have rebuttals to their prejudices. In other words, as Mouffe (2005) argues, students should not be denied the right to engage in agonistic contestation. To Mouffe (2000), agonistic pluralism presents a new way to think about democracy that is different from the traditional liberal conception of democracy as a negotiation among interests.

While one desires sites and encounters free from conflict and antagonism, if one accepts that students are autonomous beings, who ought to think for themselves, then teaching and learning have to accommodate the possibility that disagreement may appear, and therefore, have to provide spaces where differences can be confronted. As Todd and Säfström $(2008,3)$ assert, antagonistic conflicts are necessary for democracy; they give meaning to democratic politics, because they allow for the emergence and engagement of different truths. In other words, if students are to learn how to act and be in a democracy, then higher education has to nurture both the site and the expression of that democracy, without, however, abandoning the liberal democratic framework completely (Todd 2011). While students should be encouraged to voice their disagreement and prejudices, so that these might be discussed and debated, the democratic framework demands that even within conflict and disagreement, the moral responsibility of regard for the other persists. In this sense, higher education institutions do not simply prepare students to become democratic citizens, rather they introduce them to what Todd and Säfström $(2008,8)$ refer to as "the political aspects of existing in plural states, which means facing disagreement on political instead of moral terms".

In conclusion, I have argued that if one of the desired outcomes of higher education is to develop students and by implication, citizens, who are able to think for themselves, without coercion or coercing others, then, tolerance as an educational premise has to be informed by particular understandings of individual autonomy and rationality. Too often, students enter particular deliberations and disputes, not because of personal worldviews or persuasions, but because of other influences and pressures. It is therefore not unusual to hear students justifying 
certain articulations on the basis of others' beliefs and actions. In this regard, I have argued that individual autonomy and rationality are imperative to tolerant action, and in turn, that tolerance is imperative to what it means to educate, and to be educated. Students have to be afforded the necessary opportunities to engage in classroom deliberations whereby they are able to cultivate their individual autonomy through the exercise of rationality. To this end, students might be more inclined to speak out against expressions and practices of intolerance, and hence be in a better position to serve the greater purposes of higher education, which ought to be couched in moral responsibility to and for all people.

\section{ACKNOWLEDGEMENT}

Aspects of this article have been drawn from Davids, N. and Y. Waghid. 2017. Tolerance and dissent within education: On cultivating debate and understanding. New York and London: Palgrave MacMillan

\section{REFERENCES}

Aronowitz, S. and H. A. Giroux. 2000, The corporate university and the politics of education. The Educational Forum 64: 332-339.

Badat, S. 2010. The challenges of transformation in higher education and training institutions in South Africa. Paper commissioned by the Development Bank of Southern Africa. https://www.ru.ac.za/../The\%20Challenges\%20of\%20Transformation\%20in\%20High (Accessed 13 June 2016).

Badat, S. 2016. Deciphering the meanings, and explaining the South African higher education student protests of $2015-16$. wiser.wits.ac.za/.../Saleem $\% 20$ Badat $\% 20 \% 20$ Deciphering $\% 20$ the $\% 20$ Meanings,\%20a... (Accessed 15 June 2016).

Bauer-Wolf, J. 2017. The bias that a college ignores? Inside Higher Education. https://www.insidehighered.com/news/2017/06/29/lawsuit-highlights-jewish-studentsfrustrations-san-francisco-state (Accessed 20 January 2018).

Bothwell, E. 2017. Chinese students "use university education to justify intolerant views". https://www.timeshighereducation.com/news/chinese-students-use-university-education-justifyintolerant-views (Accessed 21 January 2018).

Davids, N. 2016. Does caring about those we teach make a difference to violence in schools? Implications for democratic citizenship in South Africa. International Journal of Educational Studies 3(2): 55-63.

Davids, N. and Y. Waghid. 2017. Tolerance and dissent within education: On cultivating debate and understanding. New York and London: Palgrave MacMillan

Davies, L. 2015. Educating against extremism in higher education. University World News Issue no. 381. http://www.universityworldnews.com/article.php?story=20150908141823553 (Accessed 20 January 2018).

Dawes, S. 2014. Interview with Henry A. Giroux: The neoliberalisation of higher education. https://smdawes.wordpress.com/2014/06/26/interview-with-henry-a-giroux-theneoliberalisation-of-higher-education/ (Accessed 20 January 2018).

Department of Education. 2008. Report of the Ministerial Committee on Transformation and Social Cohesion and the Elimination of Discrimination in Public Higher Education Institutions. Pretoria: Government Printers. 
DoE see Department of Education.

Dreid, N. 2016. Muslim students are reportedly attacked on campuses in wake Religious Intolerance on Campus 21 of election. The Chronicle of Higher Education. http://www.chronicle. $\mathrm{com} / \mathrm{blogs} /$ ticker/muslim-students-are-reportedly-attacked-on-campuses-in-wake-of-election/ 115475 (Accessed 20 January 2018).

Fiala, A. G. 2002. Toleration and pragmatism. The Journal of Speculative Philosophy, New Series 16(2): $103-116$.

Fosnacht, K. and C. Broderick. 2017. An overlooked factor? How religion and spirituality influence students. Paper presented at the annual meeting of the American Education Researchers Association, San Antonio, TX, May 2017.

Gutmann, A. 1987. Democratic education. Princeton, NJ: Princeton University Press.

Hall, M. 2016. South Africa's student protests have lessons for all universities. Higher Education Network. https://www.theguardian.com/higher-education-network/2016/mar/03/south-africasstudent-protests-have-lessons-for-all-universities (Accessed 15 June 2016).

Giroux, H. A. 1992. Educational leadership and the crisis of democratic government. Educational Researcher 21(4): 4-11.

Giroux, H. A. and A. Samalavicius. 2016. Higher education and neoliberal temptation: A conversation with Henry Giroux. www.eurozine.com/articles/2016-05-04-giroux-en.html (Accessed 15 June 2016).

Hughes, L. and N. Harley. 2015. Students clash with police during protest in central London over university fees. http://www.telegraph.co.uk/news/politics/11975489/student-protest-policeviolence-latest-updates.html (Accessed 20 January 2018).

Kim, H. 2011. South Korea: Tuition fees cut after protests. University World News Issue 117. http://www.universityworldnews.com/article.php?story=20110623153900892 (Accessed 19 January 2018).

Lukianoff, G. 2017. New Report: The push against campus speakers is getting more intense. https://www.huffingtonpost.com/greg-lukianoff/new-report-the-push-again_b_5417664.html (Accessed 19 January 2018).

MacGregor, K. 2016. The human costs of student tumult - An untold story. University World News Issue 414, 21 May 2016.

MacIntyre, A. 1999. Dependent rational animals: Why human beings need the virtues. London: Duckworth.

MacIntyre, A. 2006. What is wrong with weakness of will? The Journal of Philosophy 103(6): 284-311.

Mouffe, C. 2000. The democratic paradox. London: Verso.

Mouffe, C. 2005. On the political. London, UK: Routledge.

Murphy, A. R. 1997. Tolerance, toleration, and the liberal tradition. Polity 29(4): 593-623.

Oshana, M. 1998. Personal autonomy and society. Journal of Social Philosophy 29(1): 81-102.

Pring, R. 2103. What is an educated person? Address given to the Education Forum NUI Maynooth, 20th June 2013.

Reisberg, L. 2014. A future of growing intolerance? https://www.insidehighered.com/blogs/worldview/future-growing-intolerance (Accessed 19 January 2018).

Sandalow, T. 1991. The moral responsibilities of universities. In Moral values and higher education, ed. D. L. Thompson. Provo, Utah: Brigham Young University.

Suttner, R. 2016. Op-Ed: Student protests, an indictment of "post-apartheid" South Africa. 11 February 2016. www.dailymaverick.co.za/.../2016-02-11-op-ed-student-protests-an-indictment-of-po (Accessed 14 June 2016).

Swingler, S. 2017. \#FeesMustFall: Protests disrupt exam at UCT but varsity stays open. https://www.dailymaverick.co.za/article/2017-10-25-feesmustfall-protests-disrupt-exam-at-uct- 
but-varsity-stays-open/\#.WmbnUaiWZPY (Accessed 20 January 2018).

The Guardian. 2015. Attempts to ban speakers "put mission of universities at risk". https://www.the guardian.com/world/2015/nov/13/banning-shouting-down-speakers-universities-risk (Accessed 20 January 2018).

Todd, S. 2011. Educating beyond cultural diversity: Redrawing the boundaries of a democratic plurality. Studies in Philosophy and Education 30(2): 101-111.

Todd, S. and C. A. Säfström. 2008. Democracy, education and conflict: Rethinking respect and the place of the ethical. Journal of Educational Controversy 3(1): 1-11.

Walzer, M. 1997. On toleration. New York: Yale University Press. 